\title{
Manifestations of Sexuality of Children in the Environment of a Kindergarten
}

KEY WORDS

sexuality, sex education, preschool age

\begin{abstract}
Rapošová Petra, Manifestations of Sexuality of Children in the Environment of a Kindergarten. Kultura - Społeczeństwo - Edukacja nr 2(10) 2016, Poznań 2016, pp. 59-68, Adam Mickiewicz University Press. ISSN 2300-0422. DOI 10.14746/kse.2016.10.5.

This research project focuses on the presentation of sexuality in children before they enter the school system. The study provides theoretical basis of sexuality and sex education. Included in the research project are the result of the on site study with parents and children of the preschool and kindergarden age and also the teachers working with this target group. Results not only describe sexual presentation of the children but also the reactions of others to those presentations.
\end{abstract}

\section{Introduction}

There comes a moment in the life of some parents when they become "experts" in children within a very short period of time. Bookshops offer a lot of books that are very helpful for jumped-up parents in the era of their commencing role. Managers are thereby turning into prominent experts. Yet, even the best prepared parents can sometimes be surprised by their child's manifestations. In addition to common manifestations, infant sexuality still has the status of unnaturalness and unsuitability.

The situation slightly differs in the environment of a kindergarten. A kindergarten teacher is best aware of how to support speech development, development of mathematical concepts, how to apply various art techniques with such a specific group like that of pre-school children. Unlike parents, they have had to educate themselves for long in order to become qualified experts in all areas of the potential development of each child personality. However, the preparation of 
teachers in the area of infant sexuality is insufficient, which is, given the national ideology, understandable.

In our society, it is only hardly possible to refer to the need to talk with kids about sexuality issues during adolescence. The fact that sexuality-related manifestations may be observed with a pre-school child is accepted even more difficult; manifestations that can surprise both the parents and the teachers. Our attempt is to describe sexuality manifestations with pre-school children and possible ways of intervention with regard to such manifestations.

\section{Sexuality}

Many people confuse the term sexuality with sexual behaviour (Pondělíček 1974). We then cannot be surprised when the public has a negative attitude towards sexual education. If, for them, sexuality means the sexual behaviour only, what could sexual education that is so important for children yet rejected by our society mean for such a layman, parent or teacher.

The term sexuality is defined by many authors; we incline to the definition by Zonis who considers it to be an integral part of each human. It is part of moral values, attitudes, self-belief, surrounding, self-confidence component, sexual and reproduction health. We are separating these two components (sexual and reproduction), since a man is a sexual being despite non-reproduction for various reasons (Zonis, 1996). This is why we perceive sexuality as something that is present in the life of each individual already during the childhood, as the building of attitudes and values does not commence in adulthood.

Lukšík et al. (2003) refer to the fact that according to current findings, children have their own sexuality and a part of their concepts, activities and communication is bound to sexuality. Kids are testing and experiencing practices sometimes leading even to orgasm. Sexual manifestations and language being used by children to describe sexuality are surrounded by strong tension and tabooization from the side of adults. This statement is also confirmed by the research conducted by Sandfort and Cohen (2000). From among 25 areas contained in their questionnaire, the ones with the highest values of the occurrence and intensity of manifestations with 670 children observed have been generated. The highest occurrence of manifestations has been in the following areas: touching one's own genitals, touching breasts, interest in the opposite sex, playing doctor, questions regarding sexuality, hand masturbation, attempts to look at undressed people, touching other people's genitals. Other researches indicate that with pre-school children, there is an attempt to discover gender differences but also the way of a baby's coming into the world (Šulová, 2009; Fürst, 1997; Volbert, 2000). 


\section{Sexual education}

As already mentioned above, infant sexuality during certain periods really exists. According to Šulová et al. (2011), child's interest in sexuality starts between the $3^{\text {rd }}$ and $6^{\text {th }}$ years. We may close our eyes to this fact without accepting it or responsibly access to this side of the child personality. Whether we use the first or the second method, we are thereby forming the child's attitudes towards sexuality, which is considered to be a certain kind of sexual education.

It is typical for pre-school children that they are asking a lot of curious questions. The answers they receive help them know the surrounding world, not excluding the sexuality area. If we provide the kids with true answers, they will perceive topics related with partnership, family and sexual relationships as completely normal knowledge (Šulová et al. 2011). By talking with the kid about human body, genitals, explaining how the body is working, we are helping the child accept its own corporeality and thereby also own sexuality. If the kid comes across prudery and rejection of any references to everything that concerns genitals or sexual manifestations, it may very quickly get the impression that human body is bad and one has to ashamed of it. Parents' embitterment, punishments, finding causes of games with a sexual subtext are negatively affecting the child's psychic (Pondělíčková-Mašlová, 1976; Šilerová, 2003). This is also confirmed by Freud who has come to the conclusion based on his researches that impressions from the early period are leaving irremovable traces in the development of an individual, while creating, at the same time, predispositions for later neurotic diseases (Freud, 1989).

We believe that sexual education not only should be but also is part of each education, even despite not being specifically initiated by a parent. Poliaková et al. (1996: 5) state that the

essence and goals of sexual education are formed by everything which contributes to the education of a whole personality capable of recognizing and understanding social, moral and psychological and physiological peculiarities of individuals by gender. Thanks to this, they are able to create optimum human interactions with people of their own and of the opposite gender. We are thereby concentrating in the sexual education on the education of feelings, life values and cultivated and cultural communication between a man and a woman.

We deem a suitable sexual education in early childhood as very important, since the entire personality formation does not start only with the sexual maturation. True communication of information in the period when the child is most willing to talk with us in the area of sexuality should be part of the education at home as well as in a kindergarten. As written by Opravilová (2016), the attention 
with which the child is following us in the pre-school age and the trust the child is giving to us should be extremely binding for us as adults.

Given the nature, organization, fulfilment of educational and training goals that are subject to school laws, kindergarten is very specific. The contents of education and training in a kindergarten are provided for in the state educational programme which is the chief curriculum document (ŠPU, 2008). Following from the studies of the State Educational Programme, we have come to the conclusion that we see the sexual education at no specific place in the programme. However, the nature of the state educational programme allows the inclusion of sexual education elements in many educational areas. It is only up to a teacher how he or she will process signals and manifestations of infant sexuality.

\section{Own research}

Our research has been focused on manifestations of sexuality of pre-school children. We have been obtaining information through the quality-oriented research. A research sample has been formed by parents and teachers who are in contact with pre-school children. By using a semi-structured interview, we have prepared a contentual framework, a list of questions that the participants have been asked by us. The questions have concerned the following areas: child's verbal manifestations, child's physical manifestations, child's activities - game, drawing, watching TV, parents' childhood. Another method in our research has been the participant observation and data triangulation supported by product analysis (photo documentation, drawing, mass media). We have processed the data into five main semantic categories; however, we state those that could be used by teachers for their practice. It is, however, necessary to take into account specifics of the quality research methods. It has allowed us to obtain new insights into manifestations of infant sexuality; however, the results obtained may not be generalized for the entire population. We provide a description of manifestations of sexuality of a small sample of pre-school kids. Based on the verified procedures of teachers and parents, we formulate recommendations for practice.

\section{What the eye does not see is not burdening the mind}

We have stated in the theoretical section that pre-school children have their own sexuality and part of their concepts, activities and communication is bound to sexuality. Information that would stimulate the child's mind towards thinking about sexuality and erotica is being presented through media to a sufficient 
extent. Any indications of nakedness and erotica, whether in advertising interrupting fairytales for kids or in magazines, are being sensitively perceived by children. Mass media are largely inciting kinds towards manifestations of sexuality (viewing breasts, sex or erotica imitation, asking about gender differences, using words containing erotica and sex). Based on a theoretical analysis, we believe that manifestations of infant sexuality are not dependant on such strong effects as represented by mass media; however, they erotize the perception of sexuality by children. The above-mentioned manifestations in hands of an educator, teacher and parent may serve as a good impulse for applying sexual education.

Based on the findings, we recommend the following:

- accept manifestations arising from watching TV as incentives for a discussion. Realize the fact that through selection of TV broadcasts, we will prevent the occurrence of erotizing manifestations of infant sexuality; however, we will not silence sexuality in the child.

\section{When children suddenly do not know what to do with their hands}

Pre-school children slide into bad habits and one of them is masturbation too. Children are touching their genitals or masturbating at the time when physical tranquilization comes. It mainly occurs during watching TV and falling asleep. Children that are not masturbating may slide into other bad habits that are taking place under the same conditions. However, when removing such manifestation, we may not apply the same principles as with other bad habits (nail biting, finger, hair sucking...). Parents' procedures in this area should be deliberate. Right the sexual education whose procedures are being applied by a parent when directing child's masturbation (or touching genitals) may largely affect later attitude to sexuality.

We have come to the conclusion that children are touching their genitals at the time when physical tranquilization comes and when they need to somehow release the accumulated energy. They are solving it by using the said method which is considerably interfering with manifestations of sexuality. If parents fail to intercept the touching of genitals, it may turn into masturbation. This manifestation of sexuality is not sporadic with kids, since they are at the age when they are starting to recognize their body, while losing certainties they have been provided (dummy, falling asleep with a close person, nappies). If a combination of these factors occurs at an earlier age, then the touching of genitals and masturbation may be a domain of an earlier period. 
Based on the findings, we recommend the following:

- not to punish or humiliate children in case of manifestations such as touching genitals and masturbation;

- remind the child that it is not suitable now, since the kid has dirty hands, may cause infection and penis penis/vagina pains;

- remind the child that it is not suitable now, since such things should not be done in the presence of others, even though it is very pleasant;

- the parent should be invited to cooperate, if the masturbation of his or her child interferes with the educational and training process. Recommend the parents that by suitable intervention, they may reduce masturbation manifestations (be present during their child's falling asleep, stroke him or her, not to punish the child in case of such manifestations...).

\section{Children's curious questions}

Curious questions of kids can be calmed down by any answers. It is only up to parents and teachers whether they give the children getting to know their sexuality misleading answers or enrich them by knowledge they will need in their live. Children are accepting discussions on the topic of reproduction, differences between a man and a woman, childbirths without any scruples. They are right the adults who do not feel themselves naturally during such discussions. Teachers and parents believe that there is still time for their children to be given such knowledge and unsuitable information could represent a useless burden for the kids. Given the research results, we consider such concerns of parents, teachers and the public to be needless.

Teachers have no uniform idea of how to accede to the education in the area of genitals. Having regard to the topic and greater freedom offered by the State Educational Programme, it is natural that teachers do not know into what depth in the area of sexuality they may go with the kids.

Teachers in kindergartens have the tendencies - to the detriment of other body parts (hands, legs, brain, heart) - to reduce the knowledge of genitals, deal with such subjects marginally only, if at all. They do not mention human organs such as penis and vagina even despite their being used by the kids every day. Teachers from our research understand that it is necessary to reflect to infant sexuality being perceived in kindergartens (infant masturbation, questions, game manifestations, verbal allusions), however, the available literatures provides no advice for them in this area. 
Based on the findings, we recommend the following:

- within the framework of a description of a human body in basic anatomic categories, discuss genitals and their functions with children;

- anatomically name genitals - penis, vagina;

- in the event that children start to laugh, give them a counter-question: "What is funny about it? It is a human organ called like that. Is there anything funny about the word hand? No, it is not;

- support the subject by images; The following aids have proved to be helpful for teachers participating in our research:
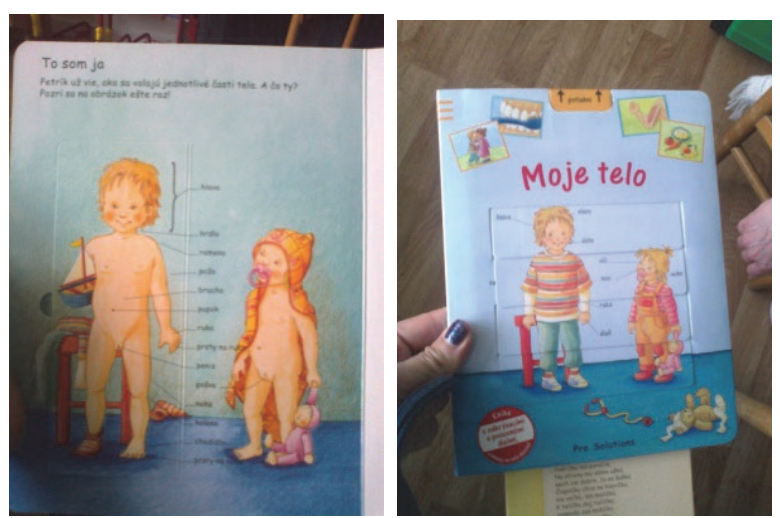

Pictures 1, 2. Pfeiffer, 2008

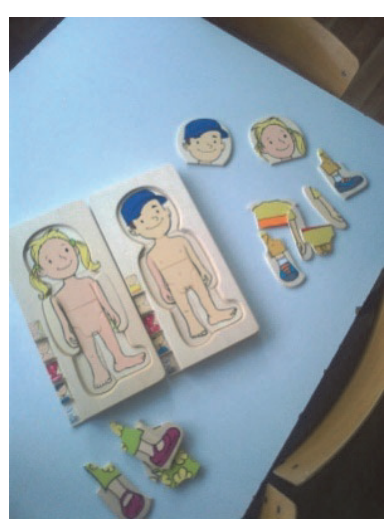

Picture 3. Your Body Layer Puzzle

\section{Game manifestations}

Thanks to a child's play, we can see what image of a child's world is offered by the society through media, how the child presents his or her family, what has attracted his or her attention in the world full of information so much that it can thereby satisfy his or her fantasy.

Dolls in a coffin: We have come to the conclusion that children are playing "household" less than before. Dolls and prams are not the toys that would be preferred when playing at home or in a kindergarten. If the children are occasionally playing "household", then it has an interesting course and role division. They are using the kitchen corner as a restaurant rather than a kitchen where a mum is cooking dinner. Boys are often playing the role of waiters and the main actors - girls must not be missing a handbag with a permanently ringing handy. Games with the missing father role are being often played by children from complete families too. Tamášová (2006) mentions problems in families of entrepreneurs as modern trends of a family. In such a family, father is less participat- 
ing in education; the family is affected by stress, higher pace of work, orientation towards consumerism and less emphasis on social certainties.

We are of the opinion that the children could be impoverished by the absence of the classical "household" game. We are following from Vágnerová (2008) who considers the thematic game to be a way of practising future roles, serving for suitable solution of certain situations, experiencing various social roles.

Based on the findings, we recommend the following:

- initiate the household game;

- the teacher will demonstrate, while using a doll in a game form, how to handle a baby, what the child care is about;

- story, fairytale dramatization should be more frequently introduced in the educational process in a kindergarten (these may also be stories about animals) where family is the central topic followed by discussions about how the family can spend time together.

The second part of this category describes the Doctor Game. The course of the game can have two forms. With the first one, the child has "innocent" intentions to treat a teddy bear or friend, while these activities are also performed with the presence of parents. With the second form of the game, the child needs to hide itself before an adult, whereas it feels a certain excitement of doing an unusual activity. Children are mutually examining genitals which cannot be seen by them every day. This is why the main initiators and actors of these games are right the kids having no siblings or having the same-sex siblings. The doctor game is a way in which children are recognizing the opposite-gender body.

Based on the findings, we recommend the following:

- Not to laugh or use other humiliation practices. Perceive this process as the possibility to talk about differences between boys and girls. If children are touching genitals of each other, explain them they this what two adults loving each other do.

\section{Influence of the environment on gender}

Since the child birth, parents are applying gender stereotypes. Effects of the social environment on gender are so strong that it can strongly affect values being built by the family. Our society has a clear idea of how a boy and girl should behave and dress and what a boy and a girl should play with. Such ideas are being intermediated by mass media. The boys' world presented by mass media diametrically differs from the world presented to the girls' population. Based on this, pre-school kids are able to let each other feel if somebody fails to observe the gender stereotypes and his or her manifestations differ from manifestations typical for the given gender. 
The society thereby makes people uniform. If a child deviates from the standard already during the pre-school age, it thereby draws attention in our society. Such attention often borders with even discrimination and concerns about the child as to the "right heterosexual" development. The desire of a boy to play with a girl's toy raises concerns of Slovak parents about the child's orientation. Children with different game preferences are critical toward themselves and later, under the influence of the surrounding, refuse to play with toys they love. Families living outside our Republic for a certain period of time are free from such thinking and are not subject to trends declared by our society through media.

Based on the findings, we recommend the following:

- prevent uniform thinking and perceive differences of children as their game preference and not as a later sexual orientation. For instance, if a girl wants to play with a car, support the girl by saying "you will surely once be a good driver". If a boy is playing with a pram and a doll, praise the child that he will once be a good father.

- prevent uniform thinking with children. Remove the first discrimination tendencies with them being demonstrated by condemning and making fun of a friend who is not following gender stereotypes. Perceive preferences of kids as primary even despite their tending to play with toys they should not be playing with given their gender.

\section{Conclusion}

Sexuality is part of each personality, not excluding the personality of pre-school children. Elements of sexual education are being applied by each teacher, since it helps form the child personality, form life values or cultural interpersonal communication. Sexual education in the environment of a kindergarten could, however, include facts and true answers to curious questions of kids; working on an attitude allowing a teacher, with no reproaches or ridicule, to accept manifestations of infant sexuality. The goal of the contribution has not been to give lessons or outrage but to obtain and describe some advice of the best experts - teachers who are working with this target group.

\section{References}

Freud S. (1990). O člověku a kultuře. Praha.

Fürst M. (1997). Psychologie. Olomouc.

Lukšík I., Supeková M. (2003). Sexualita a rodovost'. Bratislava.

Opravilová E. (2016). Predškolní pedagogika. Praha. 
Pfeiffer A. (2008). Moje telo. Bratislava.

Poliaková E., Zátopek P. (1996). Učitel a sexuálna výchova. [In:] Učitel a sexuálna výchova. Nitra.

Pondělíček I., Pondělíčková-Mašlová J. (1974). Lidská sexualita. Praha.

Sandfort T.G.M., Cohen Kettenis P.T. (2000). Sexual behavior in Duch and Belgian Children as Observed by thein Mothersi. [In:] Childhood Sexuality, Normal Sexual Behavior and Development. New York.

Šilerová L. (2003). Sexuální výchova, jak a proč mluvit s dětmi o sexualite. Praha.

Štátny vzdělávací program, ISCED 0 - predprimárne vzdelávanie. (2009). Štátny pedagogický ústav, 2009. [cit. 2010-03-28]. http://www.minedu.sk/index.php?lang=sk\&rootId=2319.

Štátny vzdělávací program, ISCED 0 - predprimárne vzdelávanie. (2016). Štátny pedagogický ústav, 2016. [cit. 2016-10-25]. Dostupné http://www.statpedu.sk/sites/default/files/nove_dokumenty/ statny-vzdelavaci-program/SVP_materske_skoly_2016-17780_27322_1-10A0_6jul2016.pdf.

Šulová L. (2009). Vývoj sexuálního chování. [In:] Pedagogická a psychologická diagnostika. Praha.

Volbert R. (2000). Sexual knowledge of preschool children. [In:] Childhood Sexuality, Normal Sexual Behavior and Development. New York.

Zonis C.F. (1996). Sexualita človeka. Bratislava. 